Int J Biochem Cell Biol. 2012 December ; 44(12): 2144-2151. doi:10.1016/j.biocel.2012.08.022.

\title{
Cancer Stem Cells
}

\author{
Zuoren Yua, ${ }^{\mathrm{a}}$, Timothy G. Pestell ${ }^{\mathrm{c}}$, Michael P. Lisanti ${ }^{\mathrm{c}}$, and Richard G. Pestell ${ }^{\mathrm{b},{ }^{*}}$ \\ ${ }^{a}$ Research Center for Translational Medicine, East Hospital, Tongji University School of Medicine, \\ Shanghai 200120, China \\ bDepartment of Cancer Biology, Kimmel Cancer Center, Thomas Jefferson University, 233 South \\ $10^{\text {th }}$ St. Philadelphia PA 19107 \\ 'Department of Stem Cell Biology and Regenerative Medicine, Kimmel Cancer Center, Thomas \\ Jefferson University, 233 South $10^{\text {th }}$ St. Philadelphia PA 19107
}

\begin{abstract}
Cancer Stem Cells (CSCs) are a small subpopulation of cells within tumors with capabilities of self-renewal, differentiation, and tumorigenicity when transplanted into an animal host. A number of cell surface markers such as CD44, CD24, and CD133 are often used to identify and enrich CSCs. A regulatory network consisting of microRNAs and Wnt/ $\beta$-catenin, Notch, and Hedgehog signaling pathways controls the CSC properties. The clinical relevance of CSCs has been strengthened by emerging evidence, demonstrating that CSCs are resistant to conventional chemotherapy and radiation treatment and that CSCs are very likely to be the origin of cancer metastasis. CSCs are believed to be an important target for novel anti-cancer drug discovery. Herein we summarize the current understanding of CSCs, with a focus on the role of miRNA and epithelial mesenchymal transition (EMT), and discuss the clinical application of targeting CSCs for cancer treatment.
\end{abstract}

\section{Keywords}

Cancer stem cells; tumorigenesis; relapse; metastasis; miRNA

\section{Introduction}

Stem cells are characterized by the capacity for self-renewal and the ability to differentiate into diverse specialized cell types. This concept has been extended from the embryonic stem cells (ESCs) and adult stem cells to cancer stem cells (CSCs) and induced pluripotent stem (IPS) cells. Through self-renewal, more stem cells are generated which maintain an undifferentiated status. Through differentiation, stem cells give rise to a mature cell type. Embryonic stem cells are capable of differentiating into all tissues during embryonic development. Adult stem cells play important roles in replenishing and repairing adult

\footnotetext{
(C) 2012 Elsevier Ltd. All rights reserved.

"Correspondence to: Richard G. Pestell, M.D., Ph.D. Department of Cancer Biology Thomas Jefferson University Kimmel Cancer Center 233 S $10^{\text {th }}$ Street, Suite 1050 Philadelphia, PA 19107 Tel: 215-503-5692, Fax: 215-503-9334

director@kimmelcancercenter.org. ZZuoren Yu, Ph.D. Research Center for Translational Medicine East Hospital, Tongji University School of Medicine Shanghai 200120 China zuoren.yu@gmail.com.

Publisher's Disclaimer: This is a PDF file of an unedited manuscript that has been accepted for publication. As a service to our customers we are providing this early version of the manuscript. The manuscript will undergo copyediting, typesetting, and review of the resulting proof before it is published in its final citable form. Please note that during the production process errors may be discovered which could affect the content, and all legal disclaimers that apply to the journal pertain.

There are no conflicts of interest associated with this manuscript.
} 
tissues (Lawson et al., 2009). Researchers have successfully reprogrammed somatic cells into stem-like cells - known as induced pluripotent stem cells (iPSCs) - which share many of the characteristics of ESCs (Takahashi and Yamanaka, 2006). Emerging evidence has indicated a subpopulation of stem-like cells within tumors, known as CSCs, which exhibit characteristics of both stem cells and cancer cells. In addition to self-renewal and differentiation capacities, CSCs have the ability to seed tumors when transplanted into an animal host. CSCs can be distinguished from other cells within the tumor by symmetry of their cell division and alterations in their gene expression (Rosen and Jordan, 2009).

microRNAs (miRNAs) are a class of non-coding small RNAs that are single-stranded with $\sim 20 \mathrm{nt}$ in length. miRNAs regulate the stability or translational efficiency of targeted messenger RNAs through complementary interaction with the 3'untranslated region of target genes. Over 1,000 mammalian miRNAs have been identified or predicted from mammals. It is predicted that one miRNA can target hundreds of genes. The expression of about onethird of human genes is regulated by multiple miRNAs. miRNAs have been demonstrated to regulate a broad range of biological processes including embryonic development, cell cycle, cell proliferation, tumor initiation and progression, cancer metastasis, self-renewal, and differentiation of stem cells (Yu et al., 2010a).

The role for miRNA in regulating stem cells was implicit in the original discovery of miRNA. The first two miRNAs discovered, lin- 4 and let-7, are involved in regulating the timing of larval to adult cell fates in C. elegans ((Lee et al., 1993, Reinhart et al., 2000). Expression of lin-4 and let-7 was undetectable in the early embryo, increased at late larval stage, and was highly expressed in the adult stage - indicating a potential role in promoting embryonic cell differentiation. Since the identification of miRNA that were exclusively expressed in ES cells by the Sharp laboratory (Houbaviy et al. 2003), a role for specific miRNA in stem cell iPSCs and CSCs, has been described. miRNA are differentially expressed in ES cells (Houbaviy et al., 2003). Key ES cell transcription factors are associated with promotors for miRNAs that are preferentially expressed in ES cells (Marson et al, 2008). Analysis of miRNA in human breast CSCs (hBCSCs) demonstrated concordant regulation of a subset of miRNA in hBCSCs and embryonal carcinoma cells (Shimono et al., 2009). Subsequent studies revealed both similarities, but also distinguishable differences in the miRNA expression in profiles of human iPSCs and human ESCs. Interestingly, these studies identify important differences between pluripotent cells and cancer cells. Collectively, these studies suggest both similarities and differences between subsets of stem cell states and cancer with emerging patterns, which are discussed further in Section 3 below.

\section{Cancer Stem Cells}

The first modern evidence for a role of stem cells in cancer came in 1994 with a study of human acute myeloid Leukemia (Lapidot et al., 1994), in which an AML-initiating cell population was identified from AML patients by transplantation into severe combined immune-deficient (SCID) mice. The leukemia-initiating cells were enriched on the basis of cell surface marker expression $\left(\mathrm{CD} 34^{+} / \mathrm{CD} 38^{-}\right)$. In 2003, human CSCs were identified in solid tumors, including breast (Al-Hajj et al., 2003) and brain cancer (Singh et al., 2003). The subsequent reports identified CSCs in a variety of tumors, including colon, pancreas, lung, prostate, melanoma, and glioblastoma. Notably, as few as 100 cancer stem cells were able to form tumors in non-obese diabetic/severe combined immunodeficient (NOD/SCID) mice (Al-Hajj et al., 2003).

Expression of cell surface markers such as CD44, CD24, CD29, CD90, CD133, epithelialspecific antigen (ESA), and aldehyde dehydrogenase1 (ALDH1) have been used to isolate 
and enrich CSCs from different tumors (Al-Hajj et al., 2003, Singh et al., 2003, Ginestier et al., 2007). Notably, the expression of CSC surface markers is tissue type-specific, even tumor subtype-specific. For example, $\mathrm{CD} 44^{+} \mathrm{CD} 24^{-/ \text {low }}$ Lineage and ALDH+ were characterized for breast CSCs; $\mathrm{CD} 133^{+}$for colon, brain and lung; $\mathrm{CD} 34^{+} \mathrm{CD} 8^{-}$for leukemia; $\mathrm{CD}_{4} 4^{+}$for head and neck; $\mathrm{CD} 90^{+}$for liver; $\mathrm{CD} 44^{+} / \mathrm{CD} 24^{+} / \mathrm{ESA}^{+}$for pancreas CSCs (Yu et al., 2010a).

CSCs are defined by their ability to generate more SCs (self-renewal) and to produce cells that differentiate. Asymmetric cell division achieves both tasks, as one progeny retains SC identity and the other undergoes rounds of cell division and subsequent post-mitotic differentiation. Consensus has not yet been reached on the criteria for classifying CSCs and therefore it has not been possible to definitively define the proportion of CSCs subpopulation in a given tumor, the relevance of CSCs to clinical outcome, and the origin of CSCs. Initially, CSCs were believed to represent a small fraction of the total cell population in a solid tumor, however, it has been claimed that as many as $25 \%$ of cancer cells may have the properties of CSCs (Kelly et al., 2007). There are several different theories regarding the origin of CSCs. One theory believes that CSCs arise from normal stem/progenitor cells which obtain the ability to generate tumors when encountering a special genetic mutation or environmental alteration. Some CSCs exhibit similarities to normal stem/progenitor cells in cellular property, phenotype, function, and even cell surface markers. For example, the $\mathrm{CD} 44^{+} / \mathrm{CD} 24^{-/ \text {low }}$ cell population identified as mammary gland progenitor cells resembles the $\mathrm{CD} 44^{+} \mathrm{CD} 24^{-/ \text {low }}$ Lineage $^{-}$cells used to identify CSCs from breast cancer patients.

An alternative theory for the origin of CSCs suggests that they arise from normal somatic cells which acquire stem-like characteristics and malignant behavior through genetic and/or heterotypic alterations. For example, cancer cells gain stem-like characteristics through epithelial-mesenchymal transition (EMT). The induction of EMT in immortalized human mammary epithelial cells (HMLEs) resulted in the acquisition of mesenchymal traits and expression of stem-cell markers, which are similar to those stem cell-like cells isolated from HMLE. Furthermore, these cells have an increased ability to form mammospheres (Mani et al., 2008).

EMT is driven by transcription factors, including SNAI1/2, ZEB1/2, or TWIST1/2, which increase the invasiveness of epithelial cells. In several studies, the induction of EMT enhances self-renewal and the acquisition of CSC characteristics (Ansieau et al., 2008, Mani et al., 2008, Yang et al., 2004). In contrast, several studies show that tumor cells with an epithelial phonotype survive in the circulation and form distant metastasis (Floor et al., 2011, Tsuji et al., 2008, Korpal et al., 2011, Celia-Terrassa et al., 2012).

In prostate cancer cell lines, subpopulations with a strong epithelial gene program were enriched in highly metastatic TIC, whereas mesenchymal subpopulations showed reduced TIC. Collectively, these studies illustrate the plasticity and cell-type specific characteristics governing self-renewal and mesenchymal gene interactions (Celia-Terrassa et al., 2012).

\section{CSC Function}

\section{Signaling Pathways and miRNA Regulation of Stem Cells}

CSC self-renewal and differentiation is tightly controlled by multiple regulatory networks, including cytokines from the cancer cell microenvironment. The function of several signaling pathways control cancer, including the Hedgehog, Notch, and Wnt/ $\beta$-catenin pathway have been previously reviewed (Reya and Clevers, 2005, DeSano and Xu, 2009) However, herein we review the relationship of these pathways to cellular polarity and cell division symmetry. (Figure 1A-E). 
Wnt signaling plays an important role in regulating developmental programs and in regulating stem cell function (Clevers, 2006) (Fig. 1A). Increased Wnt signaling gives rise to pituitary tumors in mice (Gaston-Massuet et al., 2011) and Wnt drives symmetrical cell divisions in stem cells (Le Grand et al., 2009). The Wnt family of genes encodes 19 cysteine-rich secreted glycoproteins that bind frizzled (Fzd) receptors (Kawano and Kypta, 2003). In canonical Wnt signaling, Wnt binding to Fzd activates disheveled (Dsh), inactivating GSK3 $\beta$, stabilizing $\beta$-catenin, and thereby inducing target genes, including cyclin D1 (Fig. 1A). A second type of receptor related to the low-density lipoprotein (LDL) receptor, known as LRP 5/6, also binds Wnt, together inducing canonical Wnt- $\beta$-catenin signaling. Dickkopf binds to and represses LRP. In non-canonical, Wnt signaling, Wnt binds Fzd and glypican to activate Dsh and thereby Rho and JNK or $\mathrm{Ca}^{+2}$ influx, NFAT, PKA and CamkII. An additional non-canonical pathway relevant to this review is the planar cell polarity pathway $(\mathrm{PCP})$ which drives symmetric cell division by enhancing planar polarization of stem cells (Le Grand et al., 2009, von Maltzahn et al., 2012). In this regard Wnt7a stimulated symmetric expansion of satellite stem cells via Fzd7 and Vangl2 (Le Grand et al., 2009).

Notch receptors are single pass transmembrane proteins. The receptor is processed in the ER and golgi resulting in cleavage, producing a glycosylated $\mathrm{Ca}^{+2}$ stabilized heterodimer. The processed receptor is translocated to the membrane where it binds ligands, members to the Delta-like and Jagged family, located in the signal-sending cells. Notch activation contributes to expansion of a variety of stem and early progenitor cells (Chiba, 2006).

Hedgehog coordinates organismal development and expansion of tissue progenitor or stem cells. The Hedgehog ligand is translated as a precursor, which undergoes autocatalytic processing to form an N-terminal fragment (HWN) (Fig. 1C). Secretion and paracrine signaling requires participation of the Dispatched proteins. HhN (including Indian hedgehog (Ihh), desert hedgehog (Dhh), and Sonic hedgehog (Shh)) bind the patched receptor (PTCH1), depressing its constitutive repression of smoothened (Smo), leading to activation of the Gli transcription factors (Fig. 1C). Compounds targeting this pathway to regulate stem cell function include cyclopamine, vismodegib, itraconazole, antibodies to PTCN and Gli3 and arsenic trioxide which interferes with Gli function. Gross talk between the Notch and Wnt pathway and with receptor tyrosine kinase (RTK) (Fig. 1D) coordinate interactions between growth factor receptor signaling and stem cell expansion (Fig. 1D).

Although primarily involved in determining organismal size and functioning as a tumor suppressor pathway, recent studies have demonstrated a role for the Hippo pathway in stem cells. (reviewed in (Zhao et al., 2010) (Fig. 1E). The hippo pathway component YAP prevents ESCs differentiation, TAZI knockdown induces differentiation of human CAI cells. High YAP expansion in a perivascular cancer stem cell compartment, suggest a role for VAP in CSC maintenance in the Hippo pathway (Fig. 1E).

LATS 1/2 are nuclear Dbf-2-related kinases homologous to the Drosophila gene Warts, which are activated by scaffold proteins (MOBS, Mps one binder kinase activator-like 1A, homologous to Drosophila Mats. Mst 1/2 are STE20 family kinase that activated by several upstream events including binding of Salvador (SAV1). Merlin (MER) and Expanded (Ex) proteins govern membrane and actin associations. Kibra enhances Hippo pathway activity by promoting activity of $M E R$ and $E X$, Hpo and Sav. Downstream of Hippo are transcriptional effectors YAP, TAZ and YKI. YAP regulates CTGF, Gli2 and other genes. Hippo intersects both the Wnt and Notch pathways, which also regulate stem cell function. 


\section{miRNA regulations of stem cells}

miRNAs regulate CSC self-renewal, differentiation, and tumorigenesis (Fig. 2). A global loss of miRNA, as observed in the Dicer or Dgcr8 knockout, results in global loss of miRNA processing and a defect in self-renewal with a failure to down-regulate stem cell specific markers. miRNA play an essential role in establishing ESC identity (Martinez and Gregory, 2010). miRNA play important functional roles in the establishment and maintenance of a core network of transcription factors and RNA binding proteins (OCT4, Sox2, Nanog, Klf4, c-Myc, Tcf3, Lin28) that ensure ESC identity. Several of these factors occupy the regulatory region of a cluster of miRNA that regulate their abundance in a coordinated manner in ESCs (Marson et al., 2008). The ESC miRNA maintain the ESC program by inhibiting the epigenetic silencing of pluripotency factors Let-7 miRNA opposes the function of ESC miRNA by repression common target genes activated by ESC miRNA. A CSC-specific miRNA expression profiles have been previously reported.

The miRNA circuitry of ESC includes miRNA promoting pluripotency (miR-290, 302, 371 families), are induced by pluripotency transcription factors (Oct, Sox2, Nanog, Tcf3, Kfl4), which also induce Lin28 and c-Myc. In contrast, proliferation or anti-stemness miRNAs (miR-134, miR296, miR-200c, miR-203, miR-183 and Let7 miRNAs) oppose the action of the pluripotent ESC miRNA (Martinez and Gregory, 2010). Although sharing many phenotypic similarities, significant differences in miRNA profiling has been found between human iPSCs and human ESCs (Chin et al., 2009, Wilson et al., 2009, Neveu et al., 2010). In several circumstances, there is some, often limited, overlap between the pluripotent stem cell miRNA signature and cancer stem cell miRNA profiles.

Altered expression of miR-142-3p, miR-451, miR-106a, miR-142-5p, miR-15b, miR-20a, miR-106b, miR-25, and miR-486 was identified in lung cancer progenitor cells (Qian et al., 2008). Shimono et al. screened 460 miRNAs in 11 breast cancer samples, and identified 37 miRNAs with altered expression in $\mathrm{CD} 44^{+} \mathrm{CD} 24^{-/ \text {low }}$ lineage ${ }^{-}$breast CSCs compared to lineage ${ }^{-}$non-tumorigenic breast cancer cells (Shimono et al., 2009).

Notably, miR-200 was down-regulated in human BCSCs, human stem cells and embryonal carcinoma cells (Fig. 2). miR-200c inhibits TGF- $\beta$-induced EMT in human breast cancer, inhibited the clonal expansion of breast cancer cells, suppressed the growth of embryonal carcinoma cells in vitro, and suppressed the ability of normal mammary stem cells to form mammary ducts and tumor formation driven by human breast CSCs in vivo (Shimono et al., 2009). A candidate effector of miR-200c mediated inhibition of BCSCs is Bmi-1. Bmi-1, a regulator of stem cell self-renewal, is one of the target genes of miR-200c (Fig. 2). Down regulation of miR-200c is accompanied by up regulation of Bmi-1 in breast cancer (Shimono et al., 2009).

The miR-302 part of the ESC, "stemness miRNA cluster," has high expression in ES cells which decreases upon cell differentiation, and is undetectable in somatic cells (Fig. 2). An Oct4/Sox2-miR-302-cyclin D1 regulatory network governing ES cell pluripotency and selfrenewal properties has been proposed (Card et al., 2008). miR-302 overexpression converts cancer cells into ES-like pluripotent stem cells associated with high expression of Oct3/4, SSEA-3, SSEA-4, Sox2, and Nanog (Lin et al., 2008).

The abundance of let-7 family members is reduced in several types of cancer, including lung and breast cancer (Takamizawa et al., 2004, Yu et al., 2007). In contrast to miR-302, let-7 expression is very low or undetectable in stem cells, including breast cancer stem cells, and increases with differentiation. It has been proposed that Let7 is a prodifferentiation factor with anti-stemness properties. Forced let-7 expression inhibits mammosphere formation, tumor formation, and metastasis of breast CSC in NOD/SCID mice (Yu et al., 2007). 
Reduced let-7 expression maintains the undifferentiated state of breast CSCs. let-7 may regulate self-renewal by targeting $H-R A S$, while regulating differentiation via $H M G A 2$ in breast CSC. Collectively, these studies suggest important similarities in the ESC and CSC miRNA expression and function.

Finally, there is an important interplay between miRNA and the regulation of factors that govern stemness through heterotypic signals. The tumor microenvironment (immune cells, cancer associated fibroblasts) signals to cancer stem cells (Fig. 2). Secreted cytokines and chemokines that may promote stem cell expansion are also regulated by miRNA. miR-17/20 inhibits IL-8 secretion to block tumor stem cell migration and metastasis (Fig. 2). The role of miRNA in regulating heterotypic signaling remains to be further explored.

\section{CSC and Cancer Therapy Resistance}

CSC can generate a tumor when transplanted into an immune-deficient animal. Most CSCs are believed to be resistant to chemo- and/or radiation- therapy, indicating the important roles CSCs play in cancer relapse and metastasis.

Tumorigenic breast cancer cells expressing high levels of CD44 and low or undetectable levels of CD24 may be resistant to chemotherapy and therefore responsible for cancer relapse. $\mathrm{Li}$ et al. examined the proportion of cell subpopulations in breast cancer tumor samples before and after standard dose chemotherapy (docetaxel, doxorubicin, cyclophosphamide and trastuzumab) (Li et al., 2008). The percentage of CD $44^{+} \mathrm{CD} 24^{-/ \text {low }}$ cells increased from a mean of $4.7 \%$ at baseline to $13.6 \%$ after 12 weeks of chemotherapy, with no significant change in the proportion of epithelial cancer cells. Meirelles $K$ et al. recently reported the resistance of human ovarian CSCs to chemotherapeutics, such as doxorubicin (Meirelles et al., 2012). These studies provide clinical evidence for a subpopulation of chemotherapy-resistant CSCs. However, a recent publication reported a controversial result from two patients on CSC resistance to therapy treatment (Zielske et al., 2011), in which radiation resistance of breast CSCs were assessed using early passage, patient-derived xenografts from two separate patients. The CD44 ${ }^{+} \mathrm{CD} 24^{-/ \text {low }}$ Lineage $^{-}$and $\mathrm{ALDH}^{+}$breast CSCs from one patients were rapidly depleted 2 weeks after treatment with radiation, accompanied by decreased tumor sphere frequency and tumorigenic capacity. In contrast, CSCs from the other patient displayed enrichment after irradiation and resistance to therapy (Zielske et al., 2011). These findings may be indicative of CSC variance in individual patients. The clinical application of CSCs in the future will have to account for the differences between individual patients.

\section{CSC Niche and Metastasis}

Niches are specialized microenvironments located within each tissue. Stem cells reside in the niche. The local tissue environment contributes to the onset and progression of tumorigenesis. The growth factors, cytokines, and small RNAs in the cellular microenvironment are essential for cell nutrition, intercellular communication, signal transduction, and cell fate (Zhang et al., 2010, Khaled et al., 2007). The mechanism by which the niche regulates CSC self-renewal, differentiation, tumorigenesis and metastasis is of fundamental importance.

Metastasis is a complex process by which primary solid tumor cells invade adjacent and distant tissues and grow into secondary tumors. Pre-metastatic niche formation may be an initial event of metastasis. Kaplan et al. demonstrated that tumor metastasis was initiated by a sequence of events dependent on cellular 'bookmarking' through site-specific delivery of CSCs to form permissive niches within target organs. Bone marrow-derived hematopoietic progenitor cells home to tumor-specific pre-metastatic sites and form cellular clusters before 
the arrival of tumor cells (Kaplan et al., 2005). Metastatic prostate cancer cells directly compete with the hematopoietic stem cell (HSC) for occupancy of the mouse HSC niche in the bone marrow - increasing the niche size enhanced metastasis, whereas decreasing the niche size compromised dissemination (Shiozawa et al., 2011). miRNA play a key role in the cellular microenvironment, as first demonstrated by $Y u$ et al. Yu determined that the miR-17-92 cluster inhibits breast cancer cell proliferation and suppresses breast tumor cell invasion and migration through altering the cancer cellular niche (Yu et al., 2010b). miR-17-92 conditioned medium inhibited human breast cancer cell migration and invasion, which was mediated by the reduced abundance of plasminogen activators, cytokeratin $8 / 18$, and IL-8.

\section{Clinical Relevance}

CSCs are a novel cancer target. Hoey et al. developed antibodies against delta like 4 ligand (DLL4), a component of Notch signaling pathway. In a mouse model of human colon cancer, anti-DLL4 inhibited the expression of Notch target genes and reduced proliferation of tumor cells. Furthermore, anti-DLL4, either alone or in combination with the chemotherapeutic agent irinotecan, reduced CSC function (Hoey et al., 2009). Jin et al. applied a monoclonal antibody $7 \mathrm{G} 3$, to the IL-3 receptor alpha chain (CD123), to treat leukemia stem cells in an AML mouse model. The 7G3 treatment reduced leukemia stem cells engraftment as IL-3-mediated intracellular signaling and self-renewal of leukemia stem cells $\left(\mathrm{CD} 34^{+} \mathrm{CD} 38^{-}\right)$was inhibited by $7 \mathrm{G} 3$ (Jin et al., 2009). Ginestier et al. tested a strategy to target breast CSCs through blockade of the IL-8 receptor CXCR1 using either a CXCR1-specific antibody or a small-molecule CXCR1 inhibitor, repertaxin. The breast CSC population was reduced after anti-CXCR1 treatment. In addition, repertaxin retarded tumor growth, inhibited metastasis, and reduced the breast CSC population in human breast cancer xenografts (Ginestier et al., 2010).

These studies were consistent with prior studies conducted in mice (Wu et al., 2008) demonstrating an immunoneutralizing antibody to IL-8 blocked breast cancer metastasis in vivo (Wu et al., 2008) as did overexpression of the cell fate determination factor Dachshund (DACH1) (Wu et al., 2011). Expression of DACH1 is lost in human breast cancer associated with poor prognosis. Endogenous DACH1 was reduced in breast cancer cell lines with high expression of CSC markers and in patient samples of the basal breast cancer phenotype. Overexpression of DACH1 in breast cancer cells reduced tumor formation in vivo and reduced mammosphere formation in vitro (Wu et al., 2011).

The gold standard for CSCs is the regeneration of a tumor that resembles the original tumor from which the CSCs was derived. However, a lack of correlation between the proportion of CSCs and clinical outcome restrains the translational application of targeting CSCs. CSCs may have the ability to resist current cancer therapies, resulting in the recurrence and metastasis of cancer. It has also been hypothesized that the proportion of CSCs within a tumor may correlate with the severity of the cancer (Diehn and Clarke, 2006). However, more clinical evidence and research is needed to demonstrate the correlation between the therapy-resistant CSC proportion in a tumor and tumor aggressiveness. Progress in identifying the CSC-specific surface markers, understanding the regulation of CSC tumorigenic capacity, and linking CSC to clinical outcomes will be helpful to drive the therapeutic application of targeting CSCs into the clinic.

\section{Acknowledgments}

This work was supported in part by grants R01CA070896, R01CA075503, R01CA132115, R01CA107382, R01CA086072, P30CA056036, The Breast Cancer Research Foundation and the Dr. Ralph and Marian C. Faulk Medical Research Trust (R.G.P.); a grant from Pennsylvania Department of Health (R.G.P.) and by 2012CB966800 
from National Basic Research Program of China and 81172515 from Natural Science Foundation of China (to Yu, Z.);

\section{References}

Al-Hajj M, Wicha MS, Benito-Hernandez A, Morrison SJ, Clarke MF. Prospective identification of tumorigenic breast cancer cells. Proc Natl Acad Sci U S A. 2003; 100:3983-3988. [PubMed: 12629218]

Ansieau S, Bastid J, Doreau A, Morel AP, Bouchet BP, Thomas C, Fauvet F, Puisieux I, Doglioni C, Piccinin S, Maestro R, Voeltzel T, Selmi A, Valsesia-Wittmann S, Caron de Fromentel C, Puisieux A. Induction of EMT by twist proteins as a collateral effect of tumor-promoting inactivation of premature senescence. Cancer Cell. 2008; 14:79-89. [PubMed: 18598946]

Card DA, Hebbar PB, Li L, Trotter KW, Komatsu Y, Mishina Y, Archer TK. Oct4/Sox2-regulated miR-302 targets cyclin D1 in human embryonic stem cells. Mol Cell Biol. 2008; 28:6426-6438. [PubMed: 18710938]

Celia-Terrassa T, Meca-Cortes O, Mateo F, de Paz AM, Rubio N, Arnal-Estape A, Ell BJ, Bermudo R, Diaz A, Guerra-Rebollo M, Lozano JJ, Estaras C, Ulloa C, Alvarez-Simon D, Mila J, Vilella R, Paciucci R, Martinez-Balbas M, de Herreros AG, Gomis RR, Kang Y, Blanco J, Fernandez PL, Thomson TM. Epithelial-mesenchymal transition can suppress major attributes of human epithelial tumor-initiating cells. J Clin Invest. 2012; 122:1849-1868. [PubMed: 22505459]

Chiba S. Notch signaling in stem cell systems. Stem Cells. 2006; 24:2437-2447. [PubMed: 16888285]

Chin MH, Mason MJ, Xie W, Volinia S, Singer M, Peterson C, Ambartsumyan G, Aimiuwu O, Richter L, Zhang J, Khvorostov I, Ott V, Grunstein M, Lavon N, Benvenisty N, Croce CM, Clark AT, Baxter T, Pyle AD, Teitell MA, Pelegrini M, Plath K, Lowry WE. Induced pluripotent stem cells and embryonic stem cells are distinguished by gene expression signatures. Cell Stem Cell. 2009; 5:111-123. [PubMed: 19570518]

Clevers H. Wnt/beta-catenin signaling in development and disease. Cell. 2006; 127:469-480. [PubMed: 17081971]

DeSano JT, Xu L. MicroRNA regulation of cancer stem cells and therapeutic implications. AAPS J. 2009; 11:682-692. [PubMed: 19842044]

Diehn M, Clarke MF. Cancer stem cells and radiotherapy: new insights into tumor radioresistance. J Natl Cancer Inst. 2006; 98:1755-1757. [PubMed: 17179471]

Floor S, van Staveren WC, Larsimont D, Dumont JE, Maenhaut C. Cancer cells in epithelial-tomesenchymal transition and tumor-propagating-cancer stem cells: distinct, overlapping or same populations. Oncogene. 2011; 30:4609-4621. [PubMed: 21643013]

Gaston-Massuet C, Andoniadou CL, Signore M, Jayakody SA, Charolidi N, Kyeyune R, Vernay B, Jacques TS, Taketo MM, Le Tissier P, Dattani MT, Martinez-Barbera JP. Increased Wingless (Wnt) signaling in pituitary progenitor/stem cells gives rise to pituitary tumors in mice and humans. Proceedings of the National Academy of Sciences of the United States of America. 2011; 108:11482-11487. [PubMed: 21636786]

Ginestier C, Hur MH, Charafe-Jauffret E, Monville F, Dutcher J, Brown M, Jacquemier J, Viens P, Kleer CG, Liu S, Schott A, Hayes D, Birnbaum D, Wicha MS, Dontu G. ALDH1 Is a Marker of Normal and Malignant Human Mammary Stem Cells and a Predictor of Poor Clinical Outcome. Cell Stem Cell. 2007; 1:555-567. [PubMed: 18371393]

Ginestier C, Liu S, Diebel ME, Korkaya H, Luo M, Brown M, Wicinski J, Cabaud O, Charafe-Jauffret E, Birnbaum D, Guan JL, Dontu G, Wicha MS. CXCR1 blockade selectively targets human breast cancer stem cells in vitro and in xenografts. J Clin Invest. 2010; 120:485-497. [PubMed: 20051626]

Hoey T, Yen WC, Axelrod F, Basi J, Donigian L, Dylla S, Fitch-Bruhns M, Lazetic S, Park IK, Sato A, Satyal S, Wang X, Clarke MF, Lewicki J, Gurney A. DLL4 blockade inhibits tumor growth and reduces tumor-initiating cell frequency. Cell Stem Cell. 2009; 5:168-177. [PubMed: 19664991]

Houbaviy HB, Murray MF, Sharp PA. Embryonic stem cell-specific MicroRNAs. Dev Cell. 2003; 5:351-358. [PubMed: 12919684]

Jin L, Lee EM, Ramshaw HS, Busfield SJ, Peoppl AG, Wilkinson L, Guthridge MA, Thomas D, Barry EF, Boyd A, Gearing DP, Vairo G, Lopez AF, Dick JE, Lock RB. Monoclonal antibody-mediated 
targeting of CD123, IL-3 receptor alpha chain, eliminates human acute myeloid leukemic stem cells. Cell Stem Cell. 2009; 5:31-42. [PubMed: 19570512]

Kaplan RN, Riba RD, Zacharoulis S, Bramley AH, Vincent L, Costa C, MacDonald DD, Jin DK, Shido K, Kerns SA, Zhu Z, Hicklin D, Wu Y, Port JL, Altorki N, Port ER, Ruggero D, Shmelkov SV, Jensen KK, Rafii S, Lyden D. VEGFR1-positive haematopoietic bone marrow progenitors initiate the pre-metastatic niche. Nature. 2005; 438:820-827. [PubMed: 16341007]

Kawano Y, Kypta R. Secreted antagonists of the Wnt signalling pathway. J Cell Sci. 2003; 116:26272634. [PubMed: 12775774]

Kelly PN, Dakic A, Adams JM, Nutt SL, Strasser A. Tumor growth need not be driven by rare cancer stem cells. Science. 2007; 317:337. [PubMed: 17641192]

Khaled WT, Read EK, Nicholson SE, Baxter FO, Brennan AJ, Came PJ, Sprigg N, McKenzie AN, Watson CJ. The IL-4/IL-13/Stat6 signalling pathway promotes luminal mammary epithelial cell development. Development. 2007; 134:2739-2750. [PubMed: 17611223]

Korpal M, Ell BJ, Buffa FM, Ibrahim T, Blanco MA, Celia-Terrassa T, Mercatali L, Khan Z, Goodarzi H, Hua Y, Wei Y, Hu G, Garcia BA, Ragoussis J, Amadori D, Harris AL, Kang Y. Direct targeting of Sec23a by miR-200s influences cancer cell secretome and promotes metastatic colonization. Nat Med. 2011; 17:1101-1108. [PubMed: 21822286]

Lapidot T, Sirard C, Vormoor J, Murdoch B, Hoang T, Caceres-Cortes J, Minden M, Paterson B, Caligiuri MA, Dick JE. A cell initiating human acute myeloid leukaemia after transplantation into SCID mice. Nature. 1994; 367:645-648. [PubMed: 7509044]

Lawson JC, Blatch GL, Edkins AL. Cancer stem cells in breast cancer and metastasis. Breast Cancer Res Treat. 2009; 118:241-254. [PubMed: 19731012]

Le Grand F, Jones AE, Seale V, Scime A, Rudnicki MA. Wnt7a activates the planar cell polarity pathway to drive the symmetric expansion of satellite stem cells. Cell Stem Cell. 2009; 4:535-547. [PubMed: 19497282]

Lee RC, Feinbaum RL, Ambros V. The C. elegans heterochronic gene lin-4 encodes small RNAs with antisense complementarity to lin-14. Cell. 1993; 75:843-854. [PubMed: 8252621]

Li X, Lewis MT, Huang J, Gutierrez C, Osborne CK, Wu MF, Hilsenbeck SG, Pavlick A, Zhang X, Chamness GC, Wong H, Rosen J, Chang JC. Intrinsic resistance of tumorigenic breast cancer cells to chemotherapy. J Natl Cancer Inst. 2008; 100:672-679. [PubMed: 18445819]

Lin SL, Chang DC, Chang-Lin S, Lin CH, Wu DT, Chen DT, Ying SY. Mir-302 reprograms human skin cancer cells into a pluripotent ES-cell-like state. RNA. 2008; 14:2115-2124. [PubMed: 18755840]

Mani SA, Guo W, Liao MJ, Eaton EN, Ayyanan A, Zhou AY, Brooks M, Reinhard F, Zhang CC, Shipitsin M, Campbell LL, Polyak K, Brisken C, Yang J, Weinberg RA. The epithelialmesenchymal transition generates cells with properties of stem cells. Cell. 2008; 133:704-715. [PubMed: 18485877]

Marson A, Foreman R, Chevalier B, Bilodeau S, Kahn M, Young RA, Jaenisch R. Wnt signaling promotes reprogramming of somatic cells to pluripotency. Cell Stem Cell. 2008; 3:132-135. [PubMed: 18682236]

Martinez NJ, Gregory RI. MicroRNA gene regulatory pathways in the establishment and maintenance of ESC identity. Cell Stem Cell. 2010; 7:31-35. [PubMed: 20621047]

Meirelles K, Benedict LA, Dombkowski D, Pepin D, Preffer FI, Teixeira J, Tanwar PS, Young RH, MacLaughlin DT, Donahoe PK, Wei X. Human ovarian cancer stem/progenitor cells are stimulated by doxorubicin but inhibited by Mullerian inhibiting substance. Proc Natl Acad Sci U S A. 2012; 109:2358-2363. [PubMed: 22308459]

Neveu P, Kye MJ, Qi S, Buchholz DE, Clegg DO, Sahin M, Park IH, Kim KS, Daley GQ, Kornblum HI, Shraiman BI, Kosik KS. MicroRNA profiling reveals two distinct p53-related human pluripotent stem cell states. Cell Stem Cell. 2010; 7:671-681. [PubMed: 21112562]

Qian S, Ding JY, Xie R, An JH, Ao XJ, Zhao ZG, Sun JG, Duan YZ, Chen ZT, Zhu B. MicroRNA expression profile of bronchioalveolar stem cells from mouse lung. Biochem Biophys Res Commun. 2008; 377:668-673. [PubMed: 18948085] 
Reinhart BJ, Slack FJ, Basson M, Pasquinelli AE, Bettinger JC, Rougvie AE, Horvitz HR, Ruvkun G. The 21-nucleotide let-7 RNA regulates developmental timing in Caenorhabditis elegans. Nature. 2000; 403:901-906. [PubMed: 10706289]

Reya T, Clevers H. Wnt signalling in stem cells and cancer. Nature. 2005; 434:843-850. [PubMed: 15829953]

Rosen JM, Jordan CT. The increasing complexity of the cancer stem cell paradigm. Science. 2009; 324:1670-1673. [PubMed: 19556499]

Shimono Y, Zabala M, Cho RW, Lobo N, Dalerba P, Qian D, Diehn M, Liu H, Panula SP, Chiao E, Dirbas FM, Somlo G, Pera RA, Lao K, Clarke MF. Downregulation of miRNA-200c links breast cancer stem cells with normal stem cells. Cell. 2009; 138:592-603. [PubMed: 19665978]

Shiozawa Y, Pienta KJ, Taichman RS. Hematopoietic stem cell niche is a potential therapeutic target for bone metastatic tumors. Clin Cancer Res. 2011; 17:5553-5558. [PubMed: 21676926]

Singh SK, Clarke ID, Terasaki M, Bonn VE, Hawkins C, Squire J, Dirks PB. Identification of a cancer stem cell in human brain tumors. Cancer Res. 2003; 63:5821-5828. [PubMed: 14522905]

Takahashi K, Yamanaka S. Induction of pluripotent stem cells from mouse embryonic and adult fibroblast cultures by defined factors. Cell. 2006; 126:663-676. [PubMed: 16904174]

Takamizawa J, Konishi H, Yanagisawa K, Tomida S, Osada H, Endoh H, Harano T, Yatabe Y, Nagino M, Nimura Y, Mitsudomi T, Takahashi T. Reduced expression of the let-7 microRNAs in human lung cancers in association with shortened postoperative survival. Cancer Res. 2004; 64:37533756. [PubMed: 15172979]

Tsuji T, Ibaragi S, Shima K, Hu MG, Katsurano M, Sasaki A, Hu GF. Epithelial-mesenchymal transition induced by growth suppressor p12CDK2-AP1 promotes tumor cell local invasion but suppresses distant colony growth. Cancer Res. 2008; 68:10377-10386. [PubMed: 19074907]

von Maltzahn J, Bentzinger CF, Rudnicki MA. Wnt7a-Fzd7 signalling directly activates the Akt/ mTOR anabolic growth pathway in skeletal muscle. Nat Cell Biol. 2012; 14:186-191. [PubMed: 22179044]

Wilson KD, Venkatasubrahmanyam S, Jia F, Sun N, Butte AJ, Wu JC. MicroRNA profiling of humaninduced pluripotent stem cells. Stem Cells Dev. 2009; 18:749-758. [PubMed: 19284351]

Wu K, Jiao X, Li Z, Katiyar S, Casimiro MC, Yang W, Zhang Q, Willmarth NE, Chepelev I, Crosariol M, Wei Z, Hu J, Zhao K, Pestell RG. Cell fate determination factor Dachshund reprograms breast cancer stem cell function. J Biol Chem. 2011; 286:2132-2142. [PubMed: 20937839]

Wu K, Katiyar S, Li A, Liu M, Ju X, Popov VM, Jiao X, Lisanti MP, Casola A, Pestell RG. Dachshund inhibits oncogene-induced breast cancer cellular migration and invasion through suppression of interleukin-8. Proceedings of the National Academy of Sciences of the United States of America. 2008; 105:6924-6929. [PubMed: 18467491]

Yang J, Mani SA, Donaher JL, Ramaswamy S, Itzykson RA, Come C, Savagner P, Gitelman I, Richardson A, Weinberg RA. Twist, a master regulator of morphogenesis, plays an essential role in tumor metastasis. Cell. 2004; 117:927-939. [PubMed: 15210113]

Yu F, Yao H, Zhu P, Zhang X, Pan Q, Gong C, Huang Y, Hu X, Su F, Lieberman J, Song E. let-7 regulates self renewal and tumorigenicity of breast cancer cells. Cell. 2007; 131:1109-1123. [PubMed: 18083101]

Yu Z, Baserga R, Chen L, Wang C, Lisanti MP, Pestell RG. microRNA, cell cycle, and human breast cancer. Am J Pathol. 2010a; 176:1058-1064. [PubMed: 20075198]

Yu Z, Willmarth NE, Zhou J, Katiyar S, Wang M, Liu Y, McCue PA, Quong AA, Lisanti MP, Pestell RG. microRNA 17/20 inhibits cellular invasion and tumor metastasis in breast cancer by heterotypic signaling. Proc NatlAcad Sci U S A. 2010b; 107:8231-8236.

Zhang Y, Liu D, Chen X, Li J, Li L, Bian Z, Sun F, Lu J, Yin Y, Cai X, Sun Q, Wang K, Ba Y, Wang Q, Wang D, Yang J, Liu P, Xu T, Yan Q, Zhang J, Zen K, Zhang CY. Secreted monocytic miR-150 enhances targeted endothelial cell migration. Mol Cell. 2010; 39:133-144. [PubMed: 20603081]

Zhao B, Li L, Guan KL. Hippo signaling at a glance. J Cell Sci. 2010; 123:4001-4006. [PubMed: 21084559]

Zielske SP, Spalding AC, Wicha MS, Lawrence TS. Ablation of breast cancer stem cells with radiation. Transl Oncol. 2011; 4:227-233. [PubMed: 21804918] 


\section{Cell Facts}

- Cancer stem cells (CSCs) represent a small subpopulation of cells within a tumor that express cell surface markers including CD44, CD24 and/or CD133.

- CSCs are capable of self-renewal and differentiation into non-tumorigenic cell progeny.

- CSCs are tumorigenic and capable of regenerating a tumor when transplanted into an animal host.

- Epithelial-mesenchymal transition (EMT) may either enhance or inhibit CSCs in a cell type specific manner.

- miRNAs are involved in the regulation of CSCs properties.

- CSCs are resistant to conventional treatment including chemo- and radiationtherapies.

- CSCs play important roles in cancer relapse and metastasis. 

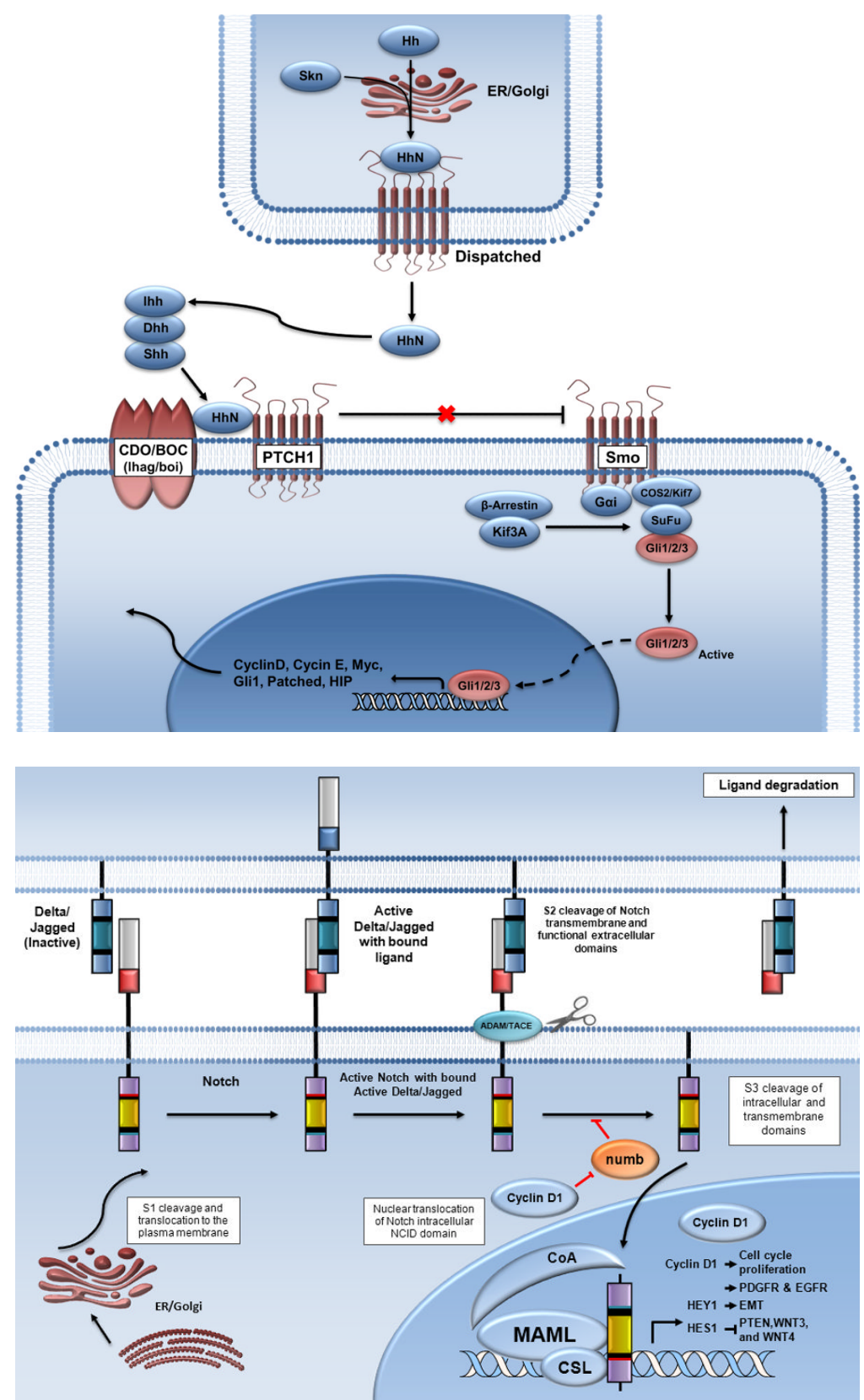

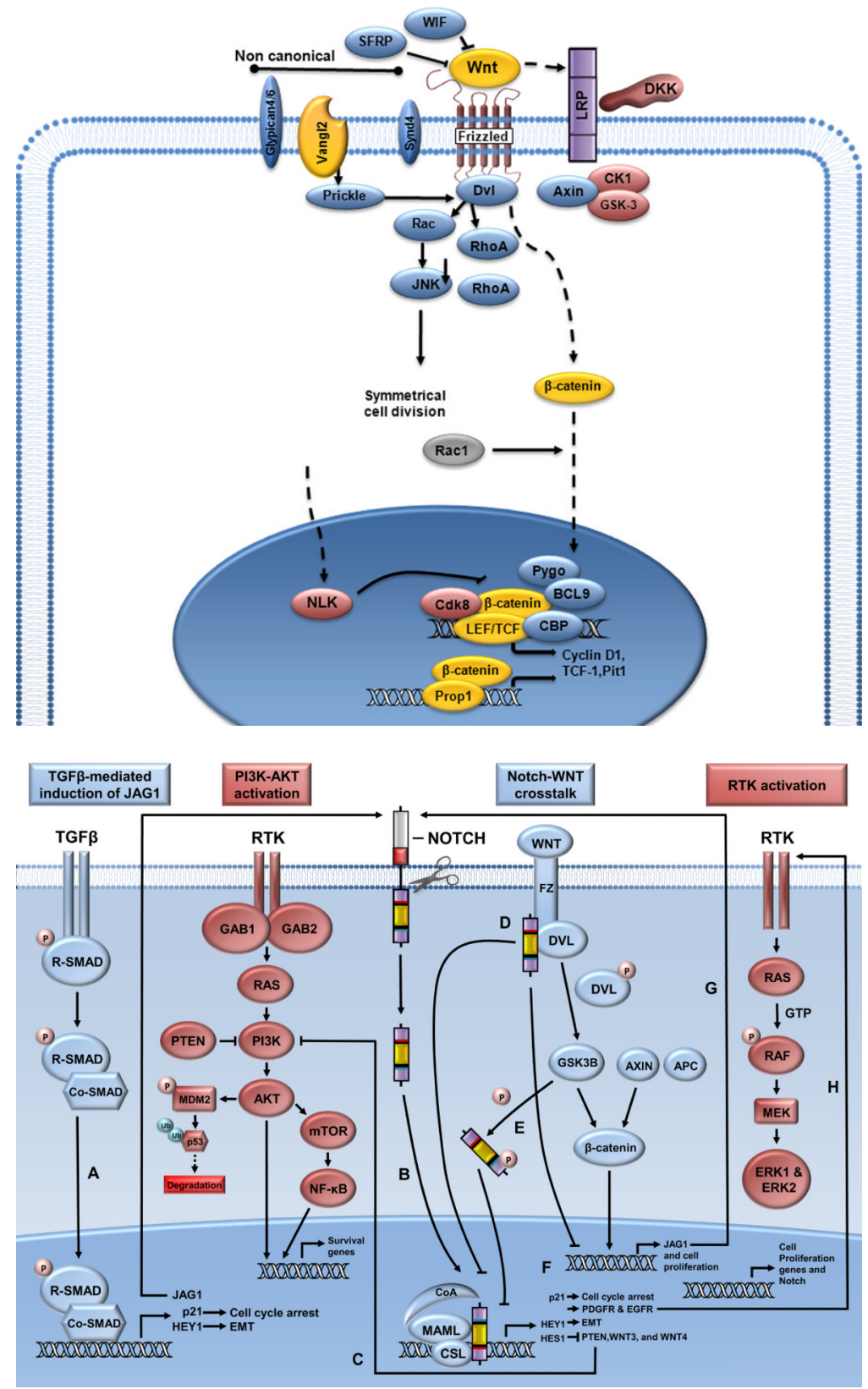


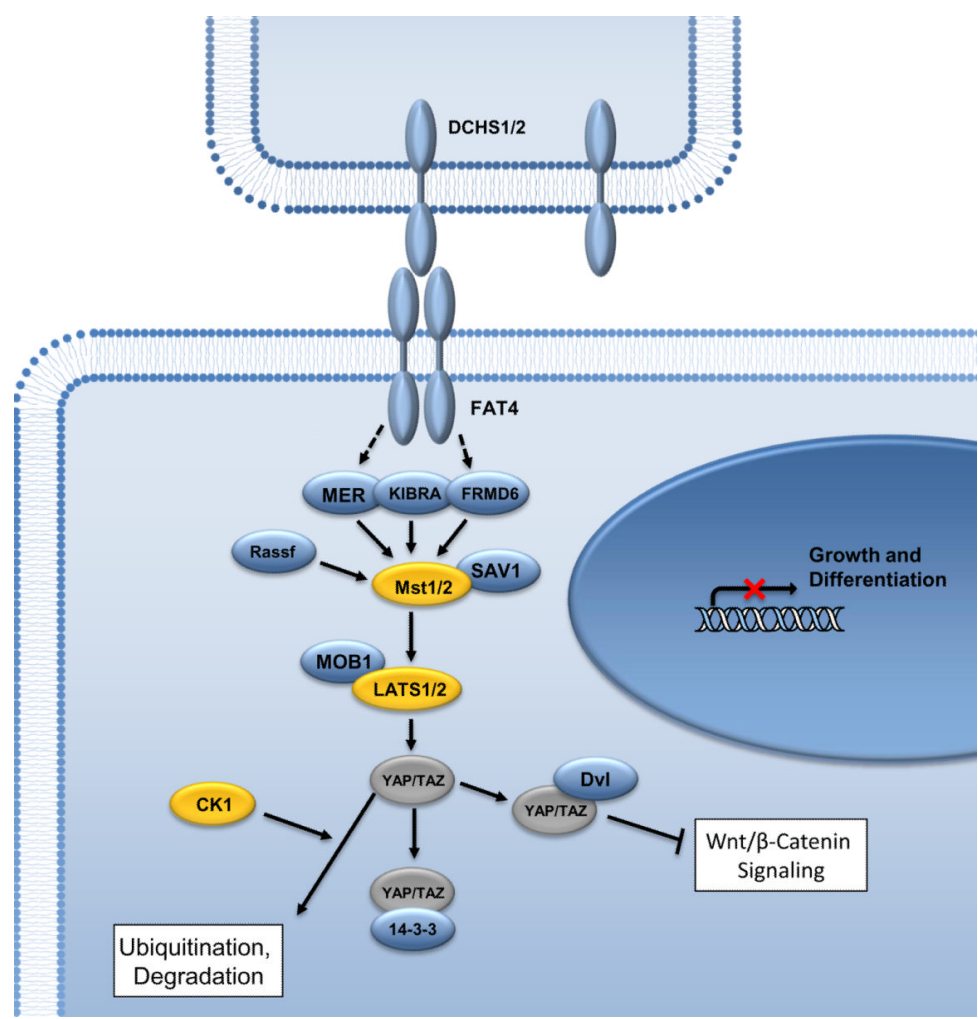

Figure 1.

Signaling pathways in regulation of gene expression, cell proliferation and differentiation. (A) Hedgehog signaling pathway; (B) Notch signaling pathway; (C) Wnt/ $\beta$-catenin signaling pathway; (D) Signaling networks with PTEN involved; (E) Hippo signaling pathway. 


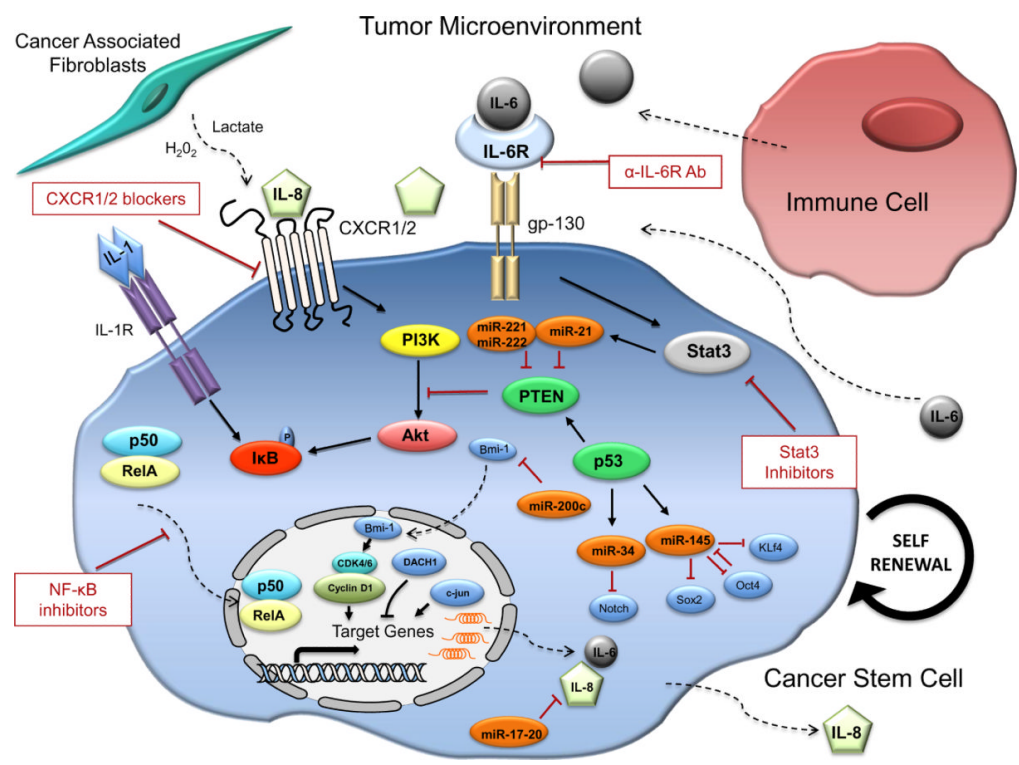

Figure 2.

Regulation of CSCs by inflammatory cytokine networks. Binding of the IL-6-IL-6R complex to gp130, and IL-8 to CXCR1/2 activates the NF- $\mathrm{kB}$ pathway via Stat3 and Akt signaling. IL-6 and IL-8 production of NF- $\kappa$ B generates a positive feedback loop that maintains constitutive pathway activation. Inhibition of pathway components by pharmacologic agents is illustrated. 